\title{
A FORCA E O MACHADO : RESISTÊNCIA ESCRAVA E QUOTIDIANO DE LIBERTOS NA COMARCA DE NAZARETH DAS FARINHAS. RECÔNCAVO BAIANO, 1830-1852
}

Wellington Castellucci Junior

Universidade Católica do Salvador

Pesquisador amparado pela FAPESB

\section{Resumo}

Este artigo é uma reflexão parcial de um estudo mais amplo, que vem sendo feito, sobre o quotidiano dos forros e as formas de resistência dos escravos na Comarca de Nazaré das Farinhas, na primeira metade do século XIX. Ele discorre sobre as tentativas de disciplinar os forros, a partir dos recrutamentos forçados para a Guarda Nacional, e as punições severas praticadas contra escravos delituosos com vistas a conter a crescente rebeldia dos cativos.

\section{Pallavros-Chave}

Escravidão $\bullet$ Resistência $\bullet$ Liberdade

\section{Abstract}

This article is a reflection from a more wide-ranging study that is being undertaken to investigate the way of life of ex-slaves and the forms of resistance of slaves in the judicial district of Nazaré das Farinhas during the first half of the nineteenth century. The article reflects on the attempts to discipline the ex-slaves through their forced conscription to the National Guard, as well as to report on the severe punishments practiced against any slaves who committed criminal acts. This treatment was carried out with the intention of containing the increasing revolt of the captive slaves.

\section{Keywords}

Slavery $\bullet$ Resistance $\bullet$ Freedom 


\section{1- Em busca da liberdade}

Em 1852 um cabra de nome Tibúrcio morreu na cadeia Pública da Cidade de Nazareth das Farinhas, importante pólo de abastecimento de víveres do Recôncavo baiano ${ }^{1}$. Ele estava preso ali havia alguns meses por ser considerado escravo fugitivo, por portar passaporte falso e sustentar o nome fictício de José Ferreira, além de estar sendo procurado na Ilha de Itaparica. A razão do seu falecimento não fora registrada nos autos do processo crime que investigou a ilegalidade dos documentos falsificados com ele encontrados. Os autos informaram, porém, que, além de rápida passagem pela Ilha, Tibúrcio, provavelmente, escapara de uma fazenda, situada numa das Paróquias do Recôncavo continental, estando os senhores à sua cata já há algum tempo. Encerrava-se ali uma longa história de luta de um escravo contra o regime escravista ${ }^{2}$.

Durante meses, enquanto trabalhava como escravo numa fazenda de Itaparica, Tibúrcio traçou estrategicamente mais uma de suas fugas em direção à liberdade. É provável que ele apostasse nas questões de morosidade da justiça e na falta de patrulha suficiente para agir e se mover entre as Paróquias à sombra da lei e dos olhos aterrorizados dos senhores, proprietários rurais da região. Àquela altura, boa parte do Recôncavo baiano estava povoada por homens e mulheres libertos, procedentes de várias partes do Império e por escravos rebeldes que davam muito trabalho aos seus senhores. Era cada vez mais difícil controlar e registrar pessoas que apareciam e logo desapareciam das Paróquias pertencentes à Comarca de Nazaré das Farinhas. Tibúrcio seria apenas mais um naquela multidão, caso não viesse a acontecer algo que denunciasse a sua condição de cativo fujão. Infelizmente os autos do processo não nos dão margem para saber como as autoridades conseguiram descobrir a trama dos documentos falsos que ele carregava.

Contudo, outras informações são possíveis de serem extraídas do processo. As esparsas evidências contidas nesse interessante documento, que apontou Tibúrcio como um dos pivôs da história de falsificação de documentos, guias, passagem e passaporte oficiais, os quais lhes deram salvo-conduto até

${ }^{1}$ A esse respeito ver BARICKMAN, B. J. Um Contraponto Baiano: açúcar, fumo, mandioca e escravidão, 1780 - 1860. Rio de Janeiro: Civilização Brasileira, 2003.

${ }^{2}$ APEB - Processo Crime contra Domingos Tellis de Santa Anna. Itaparica, 1851. Seção Judiciária, 29/1013/17. 
Nazaré, insinuam que ele parecia ter personalidade forte, que era um homem bastante perspicaz, extremamente inteligente e calculista. Também era provavelmente arredio e jamais havia se acomodado diante dos horrores da escravidão, uma vez que há indícios de que sua vida foi marcada por fugas constantes e andanças por várias paróquias e vilas do Recôncavo. Apesar de tais traços, relativos ao seu perfil, pouca coisa se sabe a respeito das peripécias e da trajetória de Tibúrcio antes de chegar a Itaparica, onde o processo começou e se constituiu na principal fonte para o desabrochar da experiência como cativo, inclusive revelando suas estreitas relações com um crioulo liberto, de nome Domingos Tellis de Santa Anna, residente naquela vila.

Olhando a descrição de suas características físicas, expostas no processo crime, somos capazes de imaginar as feições daquele cativo que lutou desesperadamente pela sua liberdade. Tibúrcio era um cabra fulo, jovem, com idade de 26 anos, possuía altura regular, tinha um corpo ordinário, os cabelos soltos, as sobrancelhas fechadas, olhos grandes e pretos, nariz, boca e orelhas regulares, alguns dentes podres na boca, falava algumas coisas pregadas, tinha uma conversa moderada, um rosto redondo, lábios finos e um princípio de barba. Curiosamente não fora registrada nenhuma marca de tortura em seu corpo ou algo que the atribuísse cicatrizes que denotassem o epíteto de escravo fujão ${ }^{3}$.

Em 1851, Tibúrcio estava a trabalhar numa fazenda/engenho, situada nas imediações da povoação de Vera Cruz ou da vila de Itaparica, na contra-costa da Ilha - o documento não aponta com exatidão a localidade, de propriedade do então, conhecido em toda a Província da Bahia, coronel Antonio Pedroso de Albuquerque, senhor de escravo e de grande fortuna baiana que morrera frustrado, por não ter recebido título de nobreza do Imperador em vista do seu envolvimento com o tráfico negreiro e suspeito de fabricação de moeda falsa ${ }^{4}$. Não é possível afirmar, com certa convicção, se ele estava ali na condição de

${ }^{3}$ Idem, Descrição das características corporais do cativo Tibúrcio.

${ }^{4}$ MATTOSO, Kátia M. de Queiroz. Bahia: A cidade do Salvador e seu mercado no século XIX. São Paulo: Hucitec; Salvador: Secretaria Municipal de Educação e Cultura, 1978, p. 275. OSÓRIO, Ubaldo. A Ilha de Itaparica: História e Tradição. Salvador: Fundação Cultural do Estado da Bahia, 1979, p. 228. É bom ressaltar que não foi somente o Coronel Pedroso de Albuquerque que se envolveu com o tráfico de escravos na Ilha de Itaparica. Higino Pires Gomes foi um dos proprietários rurais, membro do Partido Liberal que participou da Sabinada, também fora processado quando o Relâmpago desembarcou mais de 
cativo ou de jornaleiro, pois os autos não dão margem para isso. O que se sabe é que, ao se informar da notícia de que um dos seus escravos foragidos encontrava-se preso em Nazaré, o Coronel imediatamente mandou seu feitor trazêlo de volta; provavelmente ele próprio não sabia se tratar de Tibúrcio.

Durante o período de estada naquela propriedade rural, Tibúrcio exercia o ofício de carreiro, provavelmente conduzindo carroça carregada de gêneros de subsistência para o porto de embarque, onde aqueles produtos eram destinados ao Recôncavo e à capital. Na maioria das fazendas existentes em Itaparica naquela época, se produzia a cal, plantava-se mandioca, frutas tropicais, dendê e cocos, além da coleta de piaçava e a industrialização do óleo das baleias, arpoadas na baía de Todos os Santos 5 .

Uma vez que não há registros de produção de açúcar em grande escala na Ilha de Itaparica, é provável que aquela fazenda, na qual Tibúrcio se encontrava trabalhando como carreiro, fosse uma das poucas a possuir plantação de cana, pois, como informaram os autos do processo, havia um engenho naquela propriedade, o qual deveria ser usado para o fabrico do melaço e feitura da cachaça $^{6}$. O que se sabe é que, alguns senhores conjugavam a produção de um gênero principal com outros, buscando assim manter uma maior diversidade na produção e maior rentabilidade das fazendas. Foi na fazenda de Pedroso de Albuquerque que, provavelmente, teria ocorrido o primeiro encontro entre Tibúrcio e Domingos, o crioulo liberto anteriormente referido.

duas centenas de africanos na Ilha e as evidências sinalizaram para o fato de que ele havia montado toda a infra-estrutura em terra para, provisoriamente, acomodar os cativos. Ver: RODRIGUES, Jaime. O Infame Comércio. Propostas e Experiências no Final do Tráfico de Africanos para o Brasil (1800-1850). São Paulo: Editora da Unicamp, 2000, p. 156159. Também, CONRAD, Robert. Tumbeiros. O tráfico de Escravos para o Brasil. São Paulo: Brasiliense, 1985, p. 135. Sobre traficantes na Bahia e Antonio Pedroso de Albuquerque, ver XIMENES, Cristiana Ferreira Lírio. Joaquim Pereira Marinho: Perfil de um Contrabandista de Escravos na Bahia, 1828-1887. Dissertação de Mestrado, Universidade Federal da Bahia, Faculdade de Filosofia e Ciências Humanas, Mestrado em História. Salvador, UFBA, 1999.

${ }^{5}$ Ver sobre isso, ELLIS, Miriam. A Baleia no Brasil Colonial. São Paulo: Edusp, 1968. Também, SPIX e MARTIUS. Viagem pelo Brasil. 1818-1820. Vol. 2, São Paulo: Edusp, 1981, p. 139.

${ }^{6}$ Apesar de alguns viajantes do século XIX fazerem referências ao fornecimento de açúcar procedente de Itaparica, o fato é que, em termos proporcionais, aquela Ilha contribuía muito pouco considerando o volume do ouro branco produzido no Recôncavo baiano. Ver a esse respeito, SHWARTZ, Stuart B. O Recôncavo. In: Segredos Internos. Engenhos e Escravos na Sociedade Colonial. São Paulo: Cia das Letras, 1995. 
O encontro e a formação da amizade entre ambos teria ocorrido por acaso. De acordo com o auto de qualificação, Domingos Tellis era homem solteiro, de 36 anos de idade, natural da Freguesia do Passé, capital da Bahia, cujo ofício era o de ferreiro, constando apenas o nome do pai, Luis Telles de Santa Anna, sendo a mãe desconhecida. Ao que parece, Domingos, assim como tantos outros libertos, havia vagado por outras localidades do Recôncavo antes de se estabelecer em Itaparica. A história de itinerância dele não era um exemplo esporádico no quotidiano dos forros que habitavam a Ilha e o Recôncavo como um todo. No curso do século XIX, um número bastante expressivo de libertos dirigiu-se para aquela região buscando se estabelecer provisória ou definitivamente em algumas Paróquias, vivendo de variados afazeres como alternativa ao trabalho do eito. Na Ilha, alguns viraram pescadores, outros plantavam em terrenos baldios melancias e fabricavam cestos, enquanto um punhado foi viver como marinheiro de lancha, embarcadiços, estivadores, ferreiros, marceneiros, sapateiros ou arpoadores de baleias.

A maioria deles, assim como Domingos Tellis, já havia circulado por diferentes Paróquias do Recôncavo em busca de trabalho, labutando como jornaleiros, aproveitando os ciclos sazonais, mas nem sempre as condições locais lhes eram favoráveis. Assim, quando os serviços temporários se encerravam, imediatamente, eles procuravam outras povoações para se instalar. Ao que parece, Itaparica se constituía num local bastante atrativo para esses indivíduos, uma vez que a falta de um patrulhamento mais ostensivo lhes permitia um modo de vida menos disciplinado e uma relação de trabalho ligada mais ao tempo da natureza ${ }^{7}$. Um ferreiro forro, ao depor em juízo, no ano de 1884, expressou com bastante singularidade o seu modo de vida, ao ser questionado por que ele havia deixado a cidade de Cachoeira e se estabelecido em Itaparica como lugar de sua nova morada : "Respondeo que por falta de trabalho n'aquela cidade".

Assim como um número significativo de alforriados que procuraram se estabelecer em Itaparica, o crioulo Domingos, também procedente de outra re-

\footnotetext{
${ }^{7}$ O mais importante dos cronistas de época, o professor de grego Luís dos Santos Vilhena, manifestou em suas cartas preocupação com relação aos adventícios, cuja procedência era difícil identificar, que preferiam levar uma vida desregrada no litoral em vez da disciplina do trabalho no campo. Ver VILHENA, Luís dos Santos. A Bahia no Século XVIII. Vol. 03. Salvador: Editora Itapuã, 1969, p. 926.
}

${ }^{8}$ APEB, Seção Judiciária, 18/615/05. Processo Crime contra João Ricardo Bruno. Itaparica, 1884. 
gião, havia chegado há pouco tempo no lugar. Conforme seu primeiro depoimento em juízo, tinha ele, em pouco tempo, mudado de residência por três vezes, somente no período em que estava na Ilha :

... que residio no povoado da Matriz (Vera Cruz), depois mudou sua residência para o engenho do Coronel Antonio Pedroso de Albuquerque aonde concervousse com tenda aberta trabalhando por seo officio de ferreiro pelo tempo de oito meses depois do que mudou-se para o citio Camassari aonde trabalha, tendo sua dormida no lugar da Matriz .

Durante o curto período em que Domingos permaneceu morando e trabalhando no engenho do Coronel Pedroso, ele cultivou muitas amizades, sobretudo com os escravos que ali labutavam. Diariamente ele abria a sua tenda, fazia os serviços que apareciam, conversava e assistia ao labor dos cativos. Havia se passado dezesseis meses, desde que Domingos tinha se mudado do Engenho para a povoação de Vera Cruz, lugar da Matriz, quando estourou a notícia da prisão do cativo Tibúrcio na cidade de Nazareth, portando documentos falsos. Imediatamente ele foi convocado a prestar depoimento no processo que investigava o crime de falsificação de documentos que deram salvo-conduto ao escravo Tibúrcio até a dita cidade do Recôncavo. Suas ligações com os escravos da fazenda onde havia residido e, sobretudo, com o cativo preso em Nazareth o colocaram como o principal suspeito de redigir as escrituras e falsear as assinaturas do Subdelegado e do escrivão de paz titular. Assim, quando as autoridades locais passaram a investigar o caso, uma das primeiras coisas que buscaram saber foi, se após "elle dali mudar-se deixou ter aquellas relaçoens tidas quando lá morou?"10. Ao que ele respondeu de forma muito desconfiada que : "Principalmente com os escravos não teve relaçoens algumas, concervando apenas conhecimento de todos" $"$.

O que as autoridades locais estavam interessadas em saber era quais as ligações existentes entre aquele crioulo forro e um passaporte falsificado encontrado

\footnotetext{
${ }^{9}$ APEB, Seção Judiciária, 29/1013/17. Processo Crime contra o crioulo Domingos Tellis de Santa Anna. Itaparica, 1851. Depoimento do réu.

${ }^{10}$ Idem. Interrogatório ao réu Domingos Tellis de Santa Anna.

${ }^{11}$ Ibidem.
} 
em posse do escravo Tibúrcio, falecido na cadeia de Nazareth. Naquela ocasião, como já fora dito antes, o Coronel Pedroso de Albuquerque enviou o administrador de seu engenho, Antonio, para aquela cidade a fim de trazê-lo de volta ao cativeiro. Tibúrcio, no entanto, morreu na cadeia antes da chegada do emissário de Pedroso, e, no curso do processo, pairou uma ambigüidade acerca do verdadeiro senhor daquele cativo fujão.

Quando o processo foi instaurado, o crioulo Domingos já estava há meses residindo na povoação de Vera Cruz. Tinha ele arrumado os trastes, mudado da fazenda e montado sua nova tenda num local conhecido por "Camassari e tendo sua dormida no lugar da Matriz"12.

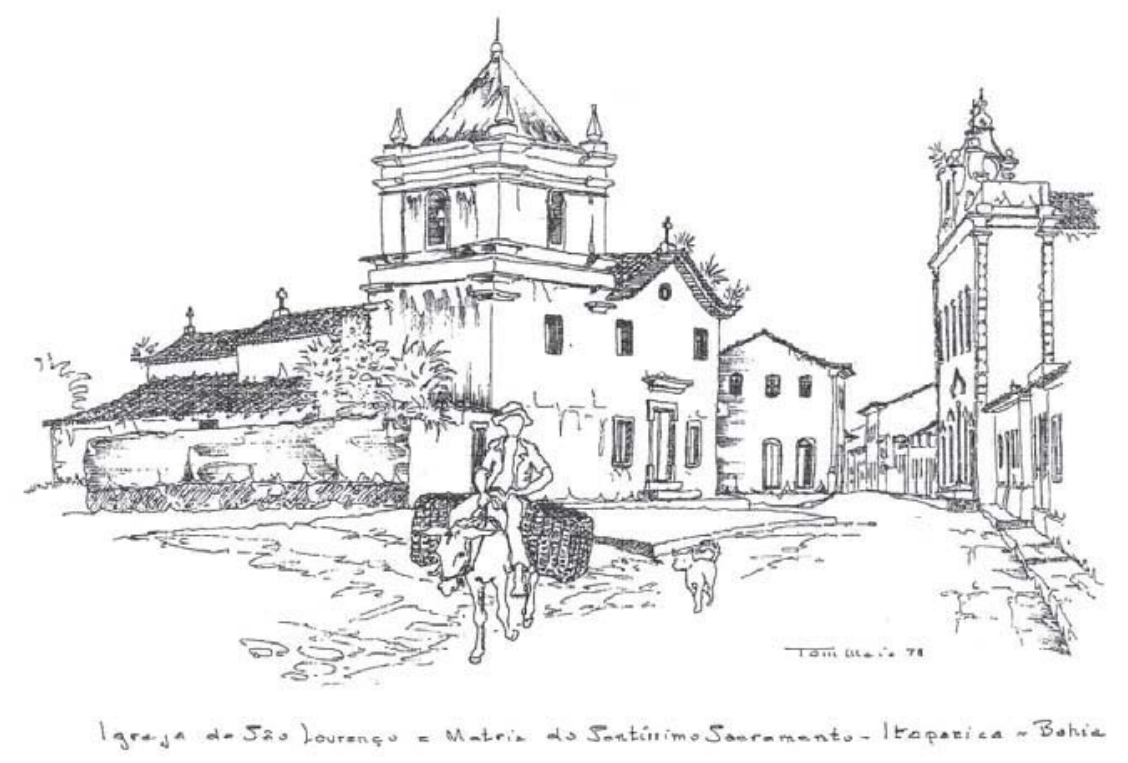

Litografia : Centro da Vila de Itaparica. Igreja de São Lourenço e Matriz do S. S. Sacramento ${ }^{13}$.

${ }^{12}$ Ibidem. Depoimento do réu.

${ }^{13}$ MAIA, Tereza Regina de Camargo. Velha Bahia de Hoje. Rio de Janeiro: Exped, 1985. 
Foi naquela povoação que Domingos começou a desempenhar temporariamente a função de Escrivão de Paz e costumava atender aos fregueses de obras em sua tenda, fazendo requerimentos e petições para os mesmos; razão pela qual : "sempre teve tinta, e papel na sua morada" ", fator agravante, como fizeram questão de salientar as autoridades no interrogatório. Consta nos autos do processo que Domingos havia assumido aquela função em razão do afastamento, por motivos de saúde, do escrivão Antonio José da Silva Borges, titular da junta de qualificação.

Como pessoa letrada e na condição de escrivão provisório de Itaparica, Domingos encontrou as condições adequadas para a falsificação dos documentos, pois, segundo o que foi apurado pelas autoridades, o mesmo fora nomeado "escrivão de paz na Junta de Qualificação que funcionou nos cinco dias da segunda reunião, e tal como esteve outros dias até que apresentou-se o efectivo"15.

Passado algum tempo, foi o escravo Tibúrcio também residir naquela mesma povoação. Ali ele adotou um novo nome, passando a se chamar José Ferreira, trabalhando tranquiilo e diariamente como carreiro, além de fazer amizades com a gente do lugar. Não há como afirmar se houve algum tipo de incentivo por parte de Domingos para que ele para lá se dirigisse. Durante o interrogatório, o próprio Domingos procuraria desconversar, afirmando que conhecera o José Ferreira, o Tibúrcio, quando este passou a morar naquela localidade, tendo-o como forro, posto que ele próprio afirmava ser liberto.

Durante meses, Tibúrcio parece ter conseguido burlar a justiça e o senhor que o procuravam, não se sabe como, residindo na povoação da Vera Cruz, localidade muito próxima da propriedade de seu suposto senhor e ali ele "girou a título de forro" ${ }^{16}$. Foi nessa ocasião que ele teria solicitado ajuda de Domingos para falsificar uma guia e um passaporte para que pudesse seguir livremente à cidade de Nazareth. O plano parece não ter sido demorado. Tudo foi, segundo a confissão do próprio Domingos, planejado às vésperas do dia de partida de Tibúrcio.

\footnotetext{
${ }^{14}$ APEB, Seção Judiciária, 29/1013/17. Processo Crime contra o crioulo Domingos Tellis de Santa Anna. Itaparica, 1851. Depoimento do réu.

${ }^{15}$ Ibidem.

${ }^{16}$ Ibidem. Pergunta feita ao réu durante o interrogatório.
} 
Assim, eles tiveram dois encontros e neles planejaram como fariam os requerimentos, a guia e o passaporte para Tibúrcio. Segundo o depoimento de Domingos, teria sido Tibúrcio quem providenciou tinta e papel para a confecção dos tais documentos. Mas a julgar pelas suas declarações, de que sempre tinha à sua disposição papel e tinta em sua tenda, por conta da função de escrivão que por hora exercia, é de se presumir que ele dispusesse de tais materiais.

Por isso, teria ele usado do poder de elaborar documentos oficiais para facilitar a confecção das guias e passaporte e, assim, dar salvo-conduto a Tibúrcio. Primeiro, ele redigiu uma petição em nome de Tibúrcio, solicitando ao Subdelegado da Freguesia de Itaparica que lhe concedesse documentos afirmando ser ele homem forro e de boa procedência. Vale a pena transcrever o astuto documento elaborado pelos dois amigos :

Diz José Ferreira cabra morador nesta Freguesia que elle suplicante tem de retirar se para a Villa de Nazarethou ou outro qualquer lugar onde le convier perçiza que Vossa Senhoria a bem do seo viver lhe passe a presente guia e atestando o pé d'este na forma da lei a seviledade e moral como cidadão para ser apresentado sendo nessessario ${ }^{17}$.

Em seguida, Domingos, usando a rubrica do Escrivão Titular, formulou o salvo-conduto para Tibúrcio, tecendo elogios acerca do bom comportamento, detalhando sua procedência e profissão. É esclarecedor visualizar a forma convincente com que Domingos escreveu o documento que seria embolsado pelo seu amigo de outrora :

Informo a Vossa Senhoria que o suplicante é residente neste Quarteirão a tres annos e trouçe guia vindo da Freguesia de Santo Amaro da Ipitanga termo da capital e foi apresentada ao Subdelegado actual Antonio Joaquim da Costa que é falecido, e o suplente desde o tempo que aqui presiste se tem comportado como homem de bem vivendo em sua vida solitaria e uzando do seo officio de carreiro lhe o que tenho a informar. 3 quarteirão da Freguesia da Vera Cruz 4 Districto da Villa de Itaparica. 12/09/1851. Lino José Borges - Inspector ${ }^{18}$

\footnotetext{
${ }^{17}$ Ibidem. Documento em anexo ao processo, falsificado pelo crioulo Domingo Tellis.

${ }^{18}$ Ibidem. Salvo-conduto escrito por Domingos Tellis de Santa Anna afiançando boa conduta de Tibúrcio. Documento constante no processo.
} 
O que teria motivado Tibúrcio a forjar, juntamente com seu amigo, documentos falsos para garantir sua viagem para Nazareth? É bem provável que essa artimanha já tivesse sido usada por ele em outras ocasiões, quando fugiu de outras paróquias, coisa que infelizmente não se pode afirmar taxativamente, tendo em vista as limitações contidas no documento. Mas, se ele havia chegado da parte continental do Recôncavo, de uma paróquia da capital ou mesmo fugido da fazendo do coronel Antonio Pedroso de Albuquerque, o fato é que agora ele precisava migrar para não cair nas malhas da justiça, fosse para não ser reenquadrado como cativo e ser castigado ou para não ser recrutado para a Guarda Nacional como processo disciplinar, no caso de ser liberto.

Para isso contou com a colaboração de um forro, o qual, inusitadamente, colocou em risco a condição de liberto, até certo ponto confortável, e muito provavelmente a própria respeitabilidade de que gozava junto aos poderes públicos locais e da população de um modo geral, uma vez que era ele escrivão nomeado pró-tempore. Somente um grande sentimento de solidariedade e tamanha afeição aos princípios da emancipação escrava poderiam levar aquele indivíduo a cometer tamanha arbitrariedade. A atitude de Domingos para com José Ferreira, o Tibúrcio, demonstrou que era nos infortúnios da escravidão que brotavam os sentimentos de compaixão, amizade e sociabilidades entre cativos e libertos e foi isso que possibilitou a liberdade de muitos deles.

Uma vez adquirida a documentação falsificada, que lhe concedia o direito de ir e vir tranqüilamente, Tibúrcio fugiu silenciosamente para a cidade de Nazareth das Farinhas subindo o rio Jaguaripe e lá passou a alardear aos quatro cantos que era forro desde os tempos de vida em outra parte do Recôncavo baiano. Depois de alguns meses residindo no lugar, Tibúrcio foi preso sob suspeita de ser escravo fugido. Tibúrcio morreu em Nazaré e seu comparsa, o forro Domingos Tellis, seria condenado a quatro anos de reclusão com trabalhos e mais multa de vinte por cento das custas judiciais, em 23 de julho de $1852^{19}$. Daquela vez, as autoridades conseguiram sufocar um sonho de liberdade e punir os envolvidos, mas, ao longo do século XIX, a história das lutas escravas traria outros contornos.

${ }^{19}$ APEB - Seção Judiciária. Autos do processo contra Domingos Tellis de Santa Anna. 


\section{2- Levantes e rebeldia de escravos e forros na Comarca de Nazaré}

A trajetória de vida do cativo Tibúrcio parece não ter sido das mais recomendadas perante os olhos dos senhores escravistas do Recôncavo baiano. Muitos desses homens de bem estavam, há muito tempo, sobressaltados, ansiosos e temerosos devido às crescentes ondas de revoltas, fugas e assassínios cometidos por escravos em suas casas, roças e lavouras, bem como de levantes de mestiços livres no curso do século XIX. Um valioso estudo, realizado recentemente sobre aquela região, revelou que a tradição oral, colhida no século $\mathrm{XX}$, ainda guardava lembranças de crimes cometidos pelos cativos contra senhores inescrupulosos da parte clássica do Recôncavo nos últimos anos de escravidão ${ }^{20}$. Nas décadas anteriores, porém, em várias Paróquias daquela região mais ao Sul, penas rigorosas haviam sido aplicadas, no sentido de conter o avanço de tais delitos e mostrar, particularmente aos escravos, que a justiça dos brancos não toleraria a crescente recalcitrância dos cativos. Eram respostas enérgicas contra as diferentes formas individuais de resistência escrava, muitas das quais manifestas no assassinato de senhores a golpes de machados. Em 1849, por exemplo, uma correspondência enviada pelo Juiz Municipal de Itaparica ao Presidente da Província informava enfaticamente que havia sido cumprida, exemplarmente, com todas as solenidades, às duas horas da tarde, a pena capital de execução do cativo Agostinho, condenado pelo assassinato do seu senhor, proprietário rural naquela localidade ${ }^{21}$.

A penalidade máxima para os infratores não deixava reservas quanto à questão de gênero ou idade, pois o que estava em jogo era a estabilidade e o controle rígido da escravidão, a despeito do prejuízo que isso traria aos proprietários. Certamente por isso é que, em 1854, o Juiz interino de Itaparica remeteu correspondência ao Presidente da Província informando a ele, e solicitando o envio

\footnotetext{
${ }^{20}$ Ver principalmente o Capítulo II. FRAGA FILHO, Walter. O Cotidiano dos Mendigos. In: Encruzilhadas da Liberdade: Histórias e Trajetórias de Escravos e Libertos na Bahia: 1870-1910. Tese de Doutorado, Instituto de Filosofia e Ciências Humanas da Universidade de Campinas, Unicamp, 2004.

${ }^{21}$ APEB-Presidência da Província. Juízes. Itaparica, 1849. Seção Colonial/Provincial, 18441859, maço 2421.
} 
da notícia ao Ministro da Justiça, do cumprimento da execução da preta Camilla, pelos delitos que a mesma havia cometido ${ }^{22}$.

As penas aplicadas aos delituosos, fossem eles escravos nacionais ou africanos, deveriam se constituir em verdadeiros autos de fé, nos moldes praticados pela Igreja Católica na Europa nos tempos Modernos contra os infiéis ${ }^{23}$. Nas vilas, o clima precedente a uma execução criava um estado de euforia para os livres e profunda angústia para os escravos. Construía-se patíbulo, contratavase algoz, convidavam geralmente um padre Franciscano para assistência espiritual do condenado em direção ao cadafalso, para ajudar-lhe a sofrer a condenação com resignação e fée ${ }^{24}$. Festejavam a negação de sua Majestade aos pedidos de clemência feitos pelos réus e preparavam o espetáculo com requintes ${ }^{25}$. Era uma evidência explícita de que os sacrifícios deveriam servir de exemplo àqueles que se aventuravam a atentar contra a ordem escravocrata. Como afirmava uma ata extraída da sessão de um júri, ocorrido em Jaguaripe no ano de 1853, o escravo acusado deveria "sofrer a pena de morte, para desagravo, e exemplo na sociedade, e por ter forma publica" $"$.

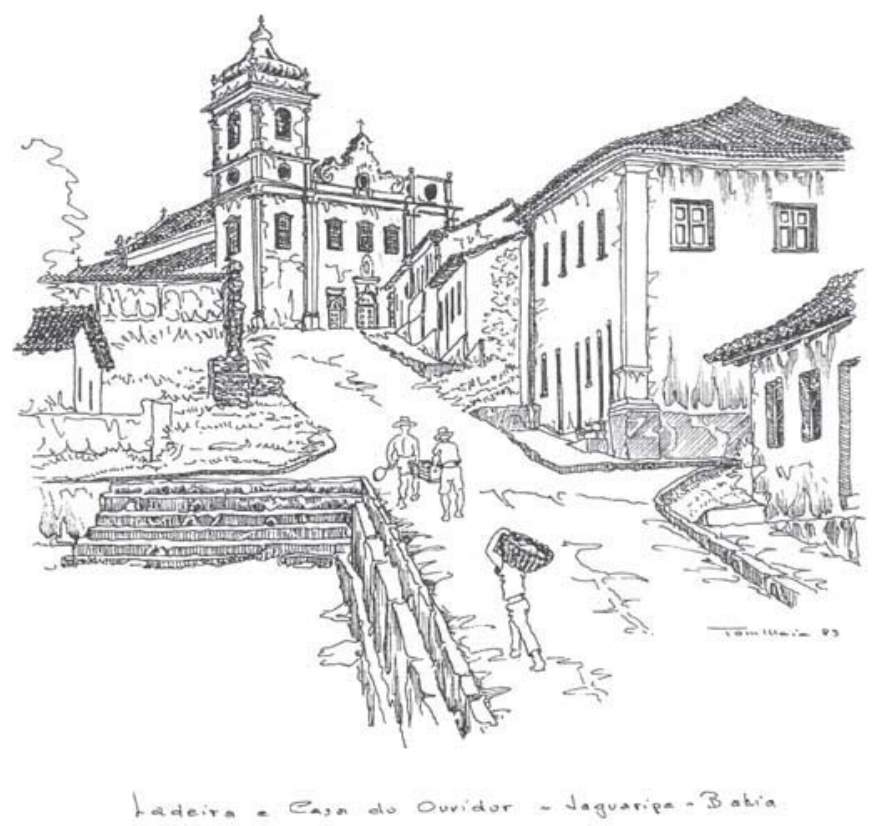

Litografia : Ladeira e casa do Ouvidor. Porto da Vila de Jaguaripe ${ }^{27}$. 
As penas deviam ser cumpridas publicamente, durante o dia e em praças onde muitas pessoas pudessem assistir eufóricas ao fatídico espetáculo, enquanto as autoridades regozijavam-se. Era uma forma de construir e sedimentar uma espécie de memória do triunfo das classes escravocratas e reafirmar a inviabilidade e o caráter inglório das lutas individuais e coletivas ante um sistema supostamente inabalável e implacável. Por isso a preocupação em cuidar das formalidades e do rigor das penalidades a serem cumpridas. Em 1837, numa correspondência expedida pelo Juiz Municipal da Comarca de Nazaré, remetida às autoridades locais de Jaguaripe, aquela autoridade recomendava detalhadamente os requintes a serem seguidos no ato de execução do réu. Vale a pena transcrever aquele inédito documento na íntegra :

Recebo neste mom o seu officio de ontem. V. respondo com alguma preça. Devi V.S. fazer levantar uma forca p se executar a sentença de morte, e a desp . a de ser satisfeita pela thesouraria da Provcia; e o réo deve ser enforcado. Se porem não ouver carrasco pode ser morto a tiro, mas procedendo-se em tudo, como se elle fosse enforcado. Deve V.S . mdar extrair humce, e intimar-lhe á, e nas 22 horas estar em outra prisão/ q. póde ser a das mulheres/ com uma guarda boa, e vigile, e então o respectivo Parocho lhe prestará todas os socorros espirituais, e o acompanhará a o lugr da forca. A força policial deve acompanhar, e executar suas ordens, bem como a nal q V.S requisitar até p. guarda ${ }^{28}$.

\footnotetext{
${ }^{22}$ APEB-Presidência da Província. Juízes. Itaparica, 1854. Seção Colonial/Provincial, 18441859, maço 2421.

${ }^{23}$ Sobre a Inquisição européia, ver, além de outros, o Trabalho de BITHENCOURT, Francisco. História das Inquisições: Portugal, Espanha e Itália. Séculos XV-XIX. São Paulo: Cia das Letras, 2000. Também, DELUMEAU, Jean. História do Medo no Ocidente. 13001800. São Paulo: Cia das Letras, 1999.

${ }^{24}$ APEB-Série Judiciário. Juízes. Itaparica, 1844-1859. Seção Colonial/Provincial, maço: 2421. 289 documentos. Doc: 2742.

${ }^{25}$ APEB-Presidência da Província. Juízes. Nazaré, 1849-1857. Seção Colonial/Provincial, maço 2505. Correspondência do Juiz de Direito da Comarca de Nazaré, André Corsino Pinto Christovão de Sousa, ao Presidente da Província, Conselheiro Francisco Gonçalves Martins. Nazaré, 20 de outubro de 1849.

${ }^{26}$ APEB-Presidência da Província. Série-juizes. Nazaré, 15 de janeiro de 1853 . Seção Colonial/Provincial, maço 2505.

${ }^{27}$ MAIA. Op. Cit.

${ }^{28}$ APEB - Presidência da Província. Juízes - Itaparica, 1837. Seção Colonial/Provincial. 1837-1844, maço 2420.
} 
Havia ainda uma preocupação com as delongas na hora da execução, pois, segundo a mesma autoridade, haveria de se ter cuidados especiais com o cumprimento da pena, de forma rápida e sem sofrimentos, para se evitar a comoção daqueles que assistiam; assim explicava aquele juiz :

Finalme deve V.S. ter todo o cuidado com o preso; e não demorar mto a execão (execução), pois bem conhece os incoves (inconvenientes) da demora. Se mais alguns esclarecimtos (esclarecimentos) V.S quiser ministralos-ei como a franquesa, e intelligcia me permitiram. Deus G. a V. S. ${ }^{29}$.

Embora tais rigores da lei pudessem, aparentemente, impressionar pela agilidade dos órgãos repressores da justiça, na maioria das vezes os poderes locais estavam a reclamar da incapacidade de fazer cumprir as ordens, provenientes da capital, em virtude da falta de pessoal, corrupção de funcionários ${ }^{30} \mathrm{e}$ excesso de burocracia que emperravam a máquina repressiva de um estado precário $^{31}$. Também a falta de contingente de força pública impedia a captura de cativos foragidos, os recrutamentos forçados aos quais eram vítimas os libertos andarilhos e as prisões de criminosos malvados que provocavam quotidianamente a insegurança das Paróquias.

Para patrulhar uma região tão grande quanto a Comarca de Nazaré as autoridades não contavam com expressivo contingente policial em proporcionalidade à quantidade de habitantes de toda a área ${ }^{32}$. Os próprios poderes locais reconheciam essa dificuldade e lamentavam a sua impotência diante dos casos aberrantes que ocorriam sistematicamente em suas paróquias. Em 24 de julho de 1835, um ano perigoso para as elites baianas, o Juiz de Paz de Itaparica enviou correspondência endereçada ao Visconde do Rio Vermelho, então Presidente da Província, alertando que :

\footnotetext{
${ }^{29} \mathrm{Idem}$

${ }^{30}$ APEB - Série Judiciária. Juízes. Nazaré, 10 de Janeiro de 1851. Seção Colonial/Provincial, 1849/1857, maço 2505.

${ }^{31}$ APEB - Série Judiciária. Juízes. Nazaré, 1851. Seção Colonial/Provincial, 1849-1857, maço 2505.

${ }^{32}$ Para uma discussão sobre a delimitação territorial do Recôncavo baiano, ver BARICKMAN, $O p$. Cit. Parte da introdução. SCHWARTZ. Op. Cit. MATTOSO, Kátia M. de Queiroz. O Recôncavo. In: A Bahia no Século XIX: uma Província no Império. Rio de Janeiro: Nova Fronteira, 1992.
} 
A força de vinte e quatro guardas nam é sufficiente para toda Comarca considerando-se as extensoens dos termos, e especialmente do de Nazareth, no qual ainda que haja quatro batalhams de Guardas Nacionais com os officiais já eleitos, nam contemplando a Freguezia de S. Miguel com gente sufficiente para outros... ${ }^{33}$.

Parece que anos mais tarde a situação continuava a mesma, pois, segundo um documento expedido pelo juiz municipal Manoel Joaquim Bahia, no ano de 1853, havia um total de 24 recrutas para tomar conta de toda aquela Comarca, assim distribuídos : A Freguesia da cidade de Nazareth contava com 3, a de Santana d'Aldeia 3, Santo Antonio de Jesus 2 e São Miguel e Laje 2. No Município de Jaguaripe a situação não era diferente : na vila havia 2 soldados, em Pirajuía e Encarnação 4 e a da Estiva 2. No Município de Itaparica havia um total de seis recrutas distribuídos eqüitativamente entre as três paróquias ${ }^{34}$.

Convenhamos, com uma força pública formada por vinte e quatro soldados, as autoridades não podiam fazer milagres, se considerado o número de habitantes formado, majoritariamente, por negros e pardos livres, justamente aqueles considerados, pelos poderes públicos, intranqüilos e perigosos. Conforme uma contabilidade elaborada por um chefe de polícia no ano de 1848, a cidade de Nazaré das Farinhas, as vilas de Jaguaripe e Itaparica, juntas, tinham uma população total de 30.244 almas livres. Desse total, apenas 9.425 foram considerados brancos $(31,16 \%)$, enquanto 5.275 eram pretos e 15.544 eram pardos. Somados os considerados não brancos, essa população de libertos compunha um percentual nada desprezível de mais de dois terços do total de habitantes $(68,83)^{35}$. Infelizmente, além das imprecisões dos dados relativos aos livres, não possuímos detalhadamente os números de cativos dessa Comarca no mesmo período, posto que os dados sobre a população escrava do Recôncavo para essa época são por demais genéricos. Tudo que sabemos a respeito do número de escravos em Nazaré é fornecido pelo Recenseamento de 1779, quando

\footnotetext{
${ }^{33}$ APEB - Série Judiciária. Presidência da Província. Juízes, Itaparica, 1835. Seção Colonial/Provincial, maço 2419.

${ }^{34}$ APEB - Série Judiciária. Presidência da Província. Juízes, Itaparica, 1853. Seção Colonial/Provincial, maço 2421.

${ }^{35}$ Quadro Numérico da População Livre de 14 Municípios d'esta Província da Bahia. Secretaria da Polícia da Bahia, 16 de fevereiro de 1848. Chefe de Polícia João Joaquim da Silva.
} 
registrou uma população cativa em torno de 1.498 indivíduos, além de 379 agregados residindo em casas de famílias ${ }^{36}$. Nas vilas de Jaguaripe e Maragogipe, por sua vez, fora registrado, já em 1816-17, um total de 11.521 escravos. No final do século anterior, no entanto, em 1781, Jaguaripe havia acusado uma população escrava em torno de 725 indivíduos, enquanto em 1846, a Freguesia da Aldeia, pertencentes a Nazaré, computou 278 cativos $^{37}$. Esses números servem para, ao menos, se fazer uma estimativa em torno da população escrava da região, mas não resolve o problema a contento.

Isso dificulta, em certa medida, uma melhor avaliação sobre a quantidade de cativos que estava trabalhando em diversos afazeres e morando naquela área ${ }^{38}$. Sabe-se, porém, através do rigoroso estudo de Barickman, que muito provavelmente nas roças de mandioca, o número de escravos muitas vezes não passava de uma ou duas unidades, trabalhando lado a lado com seus senhores no cultivo de mandioca ${ }^{39}$. Diante de tal quadro, não é difícil presumir o quanto devia ser difícil manter a ordem das coisas numa Comarca cujas distâncias entre as paróquias seria impossível percorrer a pé e se chegar em tempo hábil para socorrer as patrulhas locais em se tratando de caso de emergência ${ }^{40}$.

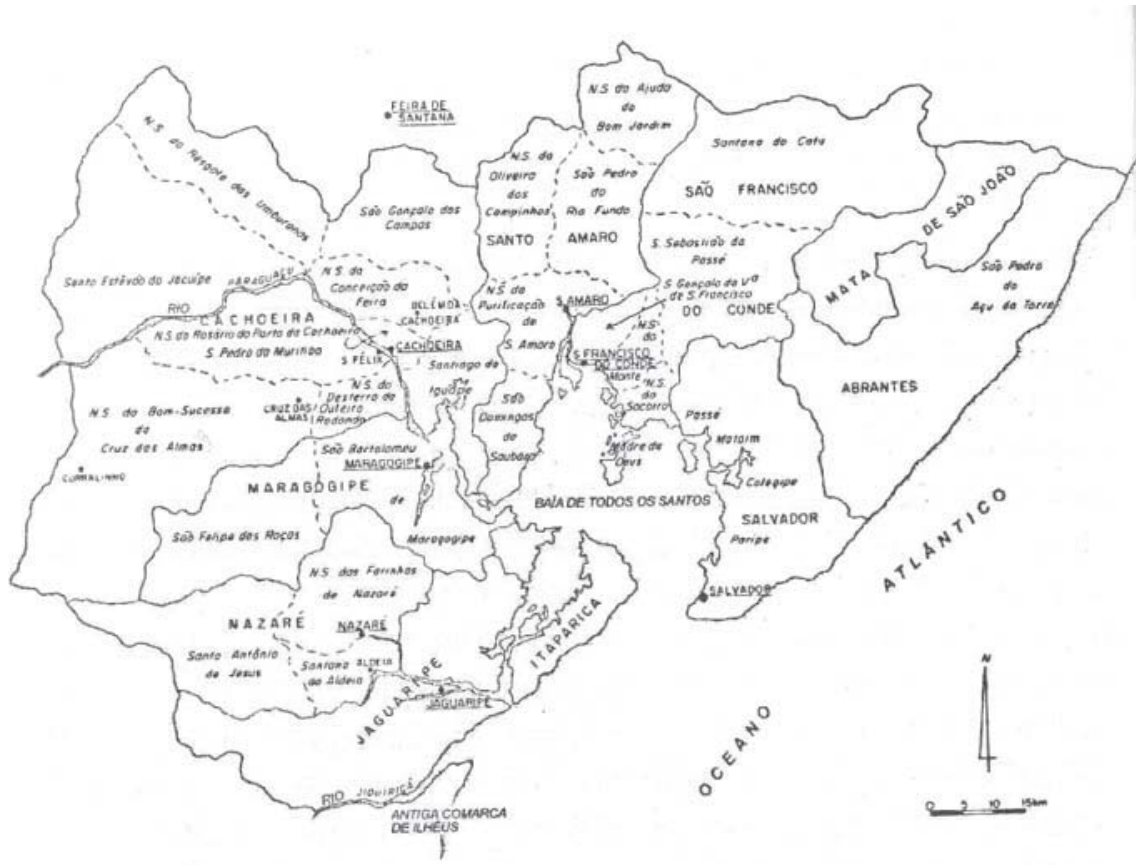

MAPA : Recôncavo Baiano ${ }^{41}$. 
Por isso, as autoridades locais estavam, por vezes, a recrutar cidadãos e, de forma esdrúxula, até escravos que andavam a cavalo de uma povoação para outra, para, momentaneamente, perseguirem escravos foragidos e forros desordeiros ${ }^{42}$.

Ainda assim, com toda a precariedade, uma quantidade surpreendente de ofícios enviados ao Presidente da Província, no curso do século XIX, acompanhando indivíduos presos pela força pública, revela que centenas de libertos estavam sendo aprisionados e remetidos para a capital a fim de serem recrutados forçosamente. Em 19 de outubro de 1838, a título de exemplo, o Juiz Municipal da vila de Itaparica, o Sr. José Plácido dos Stos., recambiou para a capital, acompanhado de um policial, um forro, de nome Manoel Caetano, recrutado sob a alegação de que o mesmo estava envolvido no furto de um escravo, além de outras ações delituosas. Porém, no mesmo ofício, aquela autoridade lamentava a incapacidade de enviar mais recrutas para a Guarda Nacional em virtude da falta de homens da força policial para capturar os malvados e perniciosos indivíduos, que

\footnotetext{
${ }^{36}$ APEB-Governo Geral/Governo da Capitania, Série: Recenseamentos/1773-1805, Seção Colonial/Provincial, maço 596.

${ }^{37}$ BARICKMAN, Op.Cit., p. 214.

${ }^{38}$ De acordo com os consagrados historiadores que estudaram o Recôncavo baiano, os dados, bastante imprecisos e parciais, sobre a população escrava daquela região giravam em torno dos seguintes valores: Em 1779 - A Freguesia de Nazaré tinha 1.493 escravos, ou o equivalente a 40,8\% da população. Em 1781 - A Vila de Jaguaripe (incluindo a Freguesia de Nazaré) possuía 725 cativos. Entre 1816-1817, as Vilas de Jaguaripe e Maragogipe tinham, juntas, 11.521 cativos. E, por fim, em 1846 - foram registrados na Freguesia da Aldeia (Município de Nazaré) 278 escravos. Ver, BARICKMAN, Mão de Obra. In: Op.Cit.; MATTOSO, Kátia M de Q. Populações da Província da Bahia. In: Op.Cit.; SCHWARTZ, Estrutura de posse de escravos na Bahia. In: Op. Cit.; REIS, João José. O Cenário da Cemiterada. In: A Morte é Uma Festa. São Paulo: Cia das Letras, 1991; FRAGA FILHO, Walter. Sociedade, economia e pobreza. In: Mendigos, Moleques e Vadios na Bahia do Século XIX. São Paulo: HUCITEC; Salvador: EDUFBA,1996.

${ }^{39}$ BARICKMAN, Um Contraponto Baiano. Cit., p. 167.

${ }^{40}$ Para se ter uma noção das distâncias entre as cidades do Recôncavo baiano, um documento elaborado pelo Juiz de Direito da Comarca de Nazaré relatava, em 1851, que as distâncias entre Nazaré e outras Cabeças de Comarcas eram as seguintes: para Valença, 10 léguas; para Cachoeira, 12 léguas; Santo Amaro, 16 léguas; para Salvador, 18 léguas; Vila de Camamu, 24 léguas, além de outras. APEB-Presidência da Província, série Judiciária, Juízes, Nazaré 1849-1857, Seção Colonial/Provincial, 2505.

${ }^{41}$ BARIKMAN, Op. Cit., p. 40.

${ }^{42}$ Ver o seguinte documento: APEB - Processo Crime contra Bernardo José Vieira. Itaparica, 1850. Seção Judiciária, doc. 29/1013/08.
} 
tranqüilamente se estabeleciam na parte litorânea da Ilha ou vagavam livremente pela vila e demais povoações ${ }^{43}$.

O processo de recrutamento de homens de cor, após a luta pela Independência na Bahia, promoveu não somente uma alteração no perfil das forças armadas regulares - posto que durante o período colonial era vedada a participação dos não-brancos nas forças mas suscitou, por um lado, uma situação paradoxal na relação entre os projetos de um estado excludente em formação e os riscos de se incluírem os que reivindicavam espaços na esfera da administração pública e no exercício da cidadania; e o exército seria um meio para isso, talvez ${ }^{44}$.

Por outro lado, os recrutamentos foram uma arma poderosa para manter a disciplina das classes "perigosas" em formação no curso do século XIX, uma vez que o impedimento de promoção de patente mantinha os libertos nas fileiras inferiores e cujas remunerações eram as mais baixas.

$\mathrm{Se}$, durante a escravidão, os oprimidos em cativeiro elaboraram diferentes mecanismos de luta e de defesa de suas conquistas obtidas diariamente, após a liberdade, os ex-escravos se viram obrigados a pensar em outras maneiras de fugir dos processos disciplinares de recrutamento, principais mecanismos de controle da classe insurgente. As fontes enfatizam que vários desses sujeitos procuravam burlar os recrutamentos, arranjando estrategicamente padrinhos locais, como padres, autoridades e senhores fazendeiros do lugar, que, pelas relações afetuosas para com eles e de concubinato com suas mães, fechavam os olhos diante do que eles faziam e lhes concediam carta de recomendação, garantindo serem de boa procedência, arrimos de família e filhos de senhoras incapazes, que eram sustentadas por eles ${ }^{45}$. Mas, houve casos também de sujei-

\footnotetext{
${ }^{43}$ APEB-Série Judiciária. Juízes. Itaparica, 1838. Seção Colonial/Provincial. 1837-1844, maço 2420. Sobre essa questão, são sugestivas as cartas de Vilhena sobre os modos de viver da gente pobre. Segundo ele, essa gente gostava muito de se estabelecer nas povoações litorâneas de modo que pudessem levar uma vida menos disciplinada. Ver VILHENA, $O p$. Cit., p. 925-926.

${ }^{44}$ Sobre essa questão é importante citar o artigo de KRAAY, Hendrik. Em outra coisa não falavam os pardos, cabras, e crioulos: O "recrutamento" de escravos na Guerra da Independência na Bahia. In: Revista Brasileira de História. São Paulo: ANPUH/Humanitas Publicações,Vol. 22, n. 43, 2002, p. 109-126.

${ }^{45}$ Ver sobre isso, DIAS, Maria Odila Leite da Silva. Forros e Brancos Pobres na Sociedade Colonial do Brasil, 1675-1835. In: História General da América Latina. Unesco, Madri, Trota, Vol. 3, 2001.
} 
tos que foram recrutados a despeito de suas alegações e que conseguiram retornar para o leito de suas famílias, à revelia do desejo das autoridades locais, esperançosas de se livrarem daquela gente incorrigível através do recrutamento $^{46}$. Um Juiz Municipal de Itaparica confessou ver-se as voltas com os libertos durante o período em que esteve à frente daquela localidade. Ele percebia aquela classe de sujeitos de modo bastante pessimista e sem perspectiva de regeneração. Tudo que estava a seu alcance, acreditava firmemente, era enviar levas desses indivíduos da Ilha para a capital e rezar para que não voltassem nunca mais. Foi dessa forma que ele, ao remeter mais um preso para Salvador, expressou um certo sentimento, o qual deveria ser compartilhado pelos membros das classes abastadas daquela época, que viam no recrutamento a possibilidade de se livrarem da incômoda presença dos libertos :

Este individuo Exmo Snr. Tem sido pr mais de huma ves daqui remetido pa recruta, e infelismte tem sempre voltado, pa continuar nos seos malvados costumes; pr isso haja V. Exa de tomar em consideração qto livo dito de livrar de huma ves esta Villa de mais este malvado. Lhe qto tenho de levar por hoje a presensa de V. Exa. ${ }^{47}$.

Outros indivíduos, com trajetória de vida semelhante à do liberto Manoel Caetano, procedentes de outras paróquias e mesmo Províncias, também passaram a viver na Ilha, de pequenos furtos e do seqüestro de escravos para vendêlos posteriormente em outras localidades. Alguns deles eram fugitivos da capital e estavam sendo procurados pela Guarda Nacional por terem participado ativamente do movimento liderado por Francisco Sabino ${ }^{48}$. Quando aquele movimento perdeu musculatura, vários de seus militantes haviam corrido para se acomodar na Ilha, temendo represálias das forças constitucionalistas. Em 14

\footnotetext{
${ }^{46}$ APEB-Seção Judiciária. Processo Crime contra Beraldo Dionísio Pimentel. Itaparica, 1853. Doc. 1/18/3. \& Série Presidência da Província. Juízes, Itaparica, 1837. Seção Colonial/Provincial, maço 2420.

${ }^{47}$ APEB - Série Presidência da Província. Juízes, Itaparica, 1838. Seção Colonial/Provincial, maço 2420.

${ }^{48}$ Refiro-me à Sabinada, movimento social de caráter separatista ocorrido na Bahia em 1837. Ver sobre isso SOUZA, Paulo Cézar. A Sabinada. A revolta Separatista da Bahia. (1837). São Paulo: Brasiliense, 1987.
} 
de dezembro daquele mesmo ano, o juiz Municipal de Itaparica enviara mais um capturado com base na seguinte acusação :

Pellos guardas policiais, Franco Xavier Ellias e Antonio Ricardo, envio a V.Excia hum preso de nome Joaqm Francisco da Solidade para recruta. Este individuo foi corneta segundo consta de hum dos batalhoens da G.N. d'essa cide. servio com os rebeldes, e agora achava-se aqui acoitado, agenciando furtos de escravos. He quanto se me oferessa levar ao conhecimto de V.Exa.

Ds. Gd. A V.Exa. Itap. 14 de dezembro de $1838^{49}$.

Além desses, os indivíduos mais visados pelas autoridades, daquela parte do Recôncavo, eram os residentes há pouco tempo no lugar e sem carta confirmando boa procedência; aqueles acusados de alcoolismo; solteiros sem responsabilidade familiar; desempregados; os brigões e turbulentos; os jogadores de cartas e três sete; os acusados de viverem de concubinato com mulheres vadias; de serem filhos sem pai legítimo; filhos de mães solteiras, além de passarem pelo constrangimento de assistirem suas genitoras serem tachadas de prostitutas de péssima conduta. Esses eram, em geral, os que seguiam recrutados para o alistamento na primeira linha do exército, como páreas incorrigíveis ${ }^{50}$. Esse tipo de discurso pragmático, explicitado na documentação judicial, expressava a ojeriza, o preconceito e o desprezo que as classes escravocratas possuíam com relação aos descendentes de escravos e homens expulsos de seus pequenos lotes de terras, que passaram a vagar pelas regiões, cujas formas de disciplinarização, impetradas pelos poderes locais, passavam pelo sistema de registro de mudança e atualização de domicílio nas paróquias e nos recrutamentos, além de outros expedientes ${ }^{51}$. Em 1849, o juiz de Nazaré, ao responder a uma correspondência procedente da capital, justificou da seguinte forma a prisão e o recrutamento

\footnotetext{
${ }^{49}$ APEB-Série Judiciária. Juizes. Itaparica, 1838. Seção Colonial/Provincial. 1837-1844, maço 2420. ${ }^{50}$ Sobre essa questão, ver CONRAD, Robert. Os Últimos Anos de Escravatura no Brasil:1850 - 1888. Rio de Janeiro: Civilização Brasileira, 1978, p. 52-54.

${ }^{51}$ DIAS, Maria Odila Leite da Silva. Sociabilidades sem História:Votantes Pobres no Império, 1824-1881. In: FREITAS, Marcos Cézar de (org.). Historiografia Brasileira em Perspectiva. São Paulo: Contexto, 1998, p. 63.
} 
de um liberto morador da Freguesia da Aldeia, Distrito pertencente à Comarca de Nazaré :

Cumprindo a ordem de V.Excia conthendo em seu despacho de16 do corrente lançada sobre representação do chefe de divisão capm do Porto da Província, em que se solicita a soltura de Antonio Rodrigues de S. Anna, recrutado para a 1 linha do exército pelo tene Coronel commde do Bm de Guardas Nacionaes da Freguesia da Aldeã deste termo, e remettido a V.Exa pelo respectivo commde superior, tendo a honra de informar a V.Exa q aquelle individuo é filho da preta Apolinária, que me disem algumas pessõas ser viúva, e outras não ser, existindo a mesma duvida quanto a ser ou não o recrutado filho único, pr que a dita preta Apolinária e seo filho a pouco tempo vierão residir em Aldêa. O que porem é certo é que a mai do recruta é uma prostituta, q de sua mesma desonestidade tira meios de subsistencia sem dependencia dos socorros de seu filho, que alias é um vadio, pois que sendo marcineiro não trabalha pelo officio, e se ocupa uma ou outra vês em alugar-se p moço da pequena pescaria que se fás no rio da povoação..... ${ }^{52}$.

Por razões como essas, o estabelecimento dos libertos num novo lugar se constituía em grande dificuldade, em função das desconfianças que pairavam sobre eles, acusados sempre de escravos fugitivos e de criminosos procurados pela polícia ${ }^{53}$. Em Itaparica, nas imediações dos povoados e da vila, ao chegarem, tratavam logo de montar uma choupana, um pequeno alpendre ou casa de adobes, se possível na parte litorânea, muito próxima do mar e dos mangues, excelente ecossistema que se apresentava como alternativa para a extração de víveres de subsistência. Para erguerem os casebres, contavam, na maioria das vezes, com a colaboração e a solidariedade de vizinhos que formavam mutirões, ou adjutórios, que iam desde o corte da madeira, extraída da mata próxima, até o fazer da massa de barro para "a tapagem das paredes da casa" $"$. Ao final da

${ }^{52}$ APEB - Presidência da Província. Juízes. Nazaré, 1849. Seção Colonial/Provincial, maço 2505. ${ }^{53}$ Ver sobre essa questão DIAS, Forros e Brancos Pobres na Sociedade Colonial do Brasil, 1675-1835. In: Op. Cit.

${ }^{54}$ APEB - Seção Judiciária. Processo crime contra Agostinho José da Costa Lima. Itaparica, 1886. 
construção, havia sempre um samba de roda e umbigada para festejar a nova morada, com direito a feijoada e bebida espirituosa.

Ali passavam a viver, quando não estavam envolvidos em furtos, de algumas atividades informais e temporárias, além da pesca e da mariscagem. Diariamente era comum a circulação de forros pelas ruas da vila vendendo mariscos e peixes frescos e moqueados, carne moqueada de baleia; buscando água na fonte da bica carregada em barris e transportada nos lombos de burros; andando a pé sem muita pressa; parados; entretidos em conversas com outros libertos ou escravos de ganhos em esquinas ou bares; entrando e saindo nas vendas e casas de molhados; passando pelas portas das igrejas a fim de ver se os santos haviam lhes dado alguma oportunidade de emprego e deixado o recado com o padre.

Nas povoações, a presença deles também se fazia nas roças circunvizinhas, nos estaleiros que reformavam embarcações e nas fábricas de cal e de outras naturezas. Estavam às vezes a viver como agregados, como rendeiros, como meeiros ou jornaleiros, em propriedades rurais ou em casas de família, envolvidos também nas atividades domésticas, onde compartilhavam as tensões quotidianas com senhores de formação cultural escravocrata, embora vissem nessa alternativa a possibilidade para fugirem do recrutamento. Suas condições materiais de subsistência, suas jornadas e ritmos de trabalho, tempo de fixação no lugar e dieta alimentar estavam condicionadas e urdidas nas conjunturas locais e específicas da sociedade escravista. Embora a presença do trabalhador livre nas lavouras tenha percorrido todo o período da escravidão, de acordo com as fontes escrutinadas, foi nas últimas décadas daquele regime que o seu número, como jornaleiros nas roças, aumentou vertiginosamente e de modo particular na Ilha de Itaparica.

Uma das grandes preocupações das autoridades locais era a de, também, através dos recrutamentos, evitar a construção de laços de solidariedade entre forros e cativos, dificultando a criação de redes de amizade, irradiadoras das formas marotas de liberdade e de fuga. Mas tudo isso não impediu a formalização desses laços, como atestou o caso de Tibúrcio e Domingos.

Nos horários vagos, escravos e forros estavam a montar divertimentos como os sambas de roda em terreiros, bailes levados a cantigas acompanhadas de violão, os quais, algumas vezes, resultavam em conflitos e terminavam com a intervenção da patrulha local. Também faziam festas, regadas a comidas feitas pelas ganhadeiras ${ }^{55}$, que fritavam peixes ou cozinhavam mariscos trazidos pelos pescadores, ou ficavam jogando três sete $e^{56}$ nas vendas e lojas de molhados, 
situadas na orla, onde se vendiam bebidas espirituosas. As autoridades locais sempre faziam batidas policiais noturnas em tais lugares e em outros, suspeitos de acomodarem vagabundos, pois os poderes públicos justificavam o aprisionamento e o recrutamento dos libertos, associando aquelas práticas sociais ao exercício da vadiagem ${ }^{57}$. Apesar do empenho da pequena força policial em prender os vadios, os resultados foram sempre minimizados por conta do número insignificante de agentes da força e da tática colaboracionista da gente do lugar, que dava guarida aos seus amigos e vizinhos procurados. Sobre isso, em 4 de dezembro de 1838, o Juiz Municipal de Itaparica encaminhou, junto com um liberto preso e recrutado, uma correspondência ao Presidente da Província. Nela, ele apresentava as credenciais do indivíduo recrutado e lamentava a falta de idoneidade dos moradores daquela paróquia que resistiam em colaborar com a ordem pública :

Envio a V. Ex preso para recruta o paisano Jose Joaquim da Costa, capturado em huma casa de jogo, da ql se evadirão outros mtos por não ter forsa suficiente $\mathrm{p}$ dar o serco; por qto tres únicos guardas policiais que aqui tenho não são soficientes pa as diligencias; como acabo agora de experimentar, visto que avansando este individuo a hum d'elles pertendeo sacar-lhe a baioneta, ao q acodindo os outros dous, deu lugar a que mais súcia q ali se achava, se evadisse. O mencionado individuo he de péssima conduta, e depois de preso tem feito na prisão grande asuada, voseferando contra as autoridades. Lhe qto tenho de levar ao conhecimto de V.Exa afim de dar as providencias q julgar conveniente a poder-se efectuar o recrutamto que de forma alguma se pode conseguir empregando gente daqui ${ }^{58}$.

\footnotetext{
${ }^{55}$ APEB - Seção Judiciária, 22/762/14. Processo Crime contra Manoel de Tal. Itaparica, 1879.

${ }^{56}$ Espécie de jogo de cartas com rodadas rápidas e finalizada com batida de um dos participantes. Sobre isso, ver MEIRELLES, Edison de Palma. Usos e costumes do antigo povoado de Itapuã. Salvador, Tipografia Bazar de antiguidades, 1987. p.12.

${ }^{57}$ Sobre a vadiagem na Bahia no século XIX, é sugestivo o trabalho de FRAGA FILHO, Mendigos, Moleques e Vadios na Bahia do Século XIX. Op. Cit.

${ }^{58}$ APEB - Série Judiciária. Juízes. Itaparica, 1838. Seção Colonial/Provincial. 1837-1844, maço 2420.
} 
Calhamaços de documentos, contendo correspondências de Juízes de Paz, Juizes Municipais e Delegados, também atestam cabalmente que as autoridades, de diferentes localidades da Comarca de Nazaré durante toda a primeira metade do século XIX, enviaram correspondências clamando para que o poder Colonial, e mais tarde o Provincial, adotasse medidas enérgicas, alertando que possíveis sublevações de escravos, concentrados em fazendas produtoras, poderiam ocorrer a qualquer momento. Numa delas, datada de nove de abril de 1838, o juiz de Direito da vila de Itaparica avisava ao Presidente da Província que armamentos deveriam ser entregues ao Juiz de Paz ou ao capitão da Companhia da Guarda Nacional, de modo a repelir os revoltosos separatistas, vindos de Salvador, ou qualquer levante de escravos que pudesse ocorrer nas imediações das povoações da Penha, Barra do Gil, Barra Grande e Conceição, áreas que concentravam grande número de escravos na Ilha ${ }^{59}$.

Essas recomendações não aconteciam por acaso. As autoridades locais de Itaparica já estavam, àquela época, ressabiadas por conta das notícias de uma possível insurreição de escravos planejada em 1829 e pela formação de um quilombo instalado nas matas, fincado no interior da Ilha, de onde, em 1835, os escravos estavam apenas esperando os seus companheiros revoltosos chegarem da Vila de Cachoeira - lugar onde residiam seu rei e rainha - por meio de canoas descendo o Rio Paraguaçu, para assassinarem as autoridades locais e fazerem a revolta triunfar ${ }^{60}$. Coincidentemente, aquele início de revolta, perpetrada pelos pretos, contou com a participação de escravos pardos pertencentes à fazenda do Coronel Antonio Pedroso de Albuquerque, aquela mesma propriedade da qual fugiria o escravo Tibúrcio anos depois.

O exacerbado temor das autoridades de levantes escravos foi expresso, de modo enfático, pelo juiz de paz de Itaparica por ocasião daquela tentativa de revolta de 1829. Segundo sua correspondência, recheada de suspense, datada de primeiro de janeiro daquele ano, já havia indícios de revoltas pelo sumiço de armas nas fortificações, às vésperas do natal, e de boatarias que circulavam nas imediações da vila no primeiro dia do ano novo. Assim como em outras

\footnotetext{
${ }^{59}$ APEB - Série Judiciária. Juízes. Itaparica, 09 de abril de 1838. Seção Colonial/Provincial, maço 2420.

${ }^{60}$ APEB - Série Judiciária. Juízes. Itaparica, 03 de janeiro de 1829. Seção Colonial/Provincial, maço 2419. \& Itaparica, 08 de fevereiro de 1835, maço 2419.
} 
oportunidades na Bahia da primeira metade do século XIX ${ }^{61}$, tudo leva a crer que os escravos de Itaparica também escolheram as datas festivas para estrategicamente prepararem suas sublevações. É possível que eles soubessem que datas comemorativas dos brancos afrouxavam ainda mais a fiscalização sobre os cativos e esse fosse o momento adequado para surpreender as autoridades. Assim falava o Juiz no primeiro dia do ano :

Neste momento, que são dez horas da noite tenho notícia pelo Tenente Coronel Francisco Antonio de Barros Galvão, que hum homem desta povoação denominado Silvestre de Santa Anna asoalha a noticia de que estão revoltados os escravos, pelo que foi imediatamente recolhido a fortaleza o mencionado Silvestre, e eu passei interinamente a dar as providencias, que me parecerão acertadas, bem como rondas, hum destacamento na costa, e hua guarda para a fortaleza, a que tudo passo a comunicar a Vossa Escelencia assima e hoje tive noticia certa que juntarão de dentro da fortaleza desta Ilha no dia 23 do passado dezembro huã pessa calibre dois, e encontra-me se sumida outra da Costa do Mar Grande, da que inda não tenho noticia certa.

Ficão quanto excelentissim Sr em instar os habitantes desta Freguesia a amanhão darei a Vossa excelência conta do resultado ${ }^{62}$.

A localização privilegiada de Itaparica favorecia a movimentação de escravos e libertos, pois os principais rios caudalosos que cortam aquela área do Recôncavo - fornecedora de açúcar, farinha e outros gêneros alimentícios - deságuam nas costas da Ilha, criando, além de um extraordinário espetáculo natural, um excelente meio de comunicação, por onde canoas, saveiros e sumacas, dirigidas por uma população suspeita e procedente de diversas localidades, subiam e desciam, sobretudo à noite, quando o lugar se tornava ainda mais inseguro e fácil de se esconder por conta da ausência de iluminação pública.

Durante toda a primeira metade do século XIX, pelo menos na área pertencente à Comarca de Nazareth, a situação no Recôncavo permaneceu tensa, tendo

\footnotetext{
${ }^{61}$ Refiro-me ao levante abortado dos escravos fugidos no Quilombo do Urubu sufocado em 1826 nas imediações da cidade do Salvador. Ver: REIS, João José. Quilombos e Revoltas Escravas no Brasil. In: Revista USP. São Paulo: Universidade de São Paulo, n. 22, 1989, p. 21. ${ }^{62}$ APEB - Série Judiciária. Juízes. Itaparica, 01 de janeiro de 1829. Seção Colonial/Provincial, maço 2419.
} 
os escravos infernizado a vida de seus senhores e as autoridades rechaçado os seus atos com violência e variadas formas de intimidação. Em parte, o aumento das tensões foi sendo alimentado pelo surto de crescimento populacional dos libertos, verificado na virada do século XVIII para o XIX, sobretudo, no que tange ao aumento do número de alforriados na Bahia ${ }^{63}$. Mas fora também pelas ameaças de repercussões da revolta dos Malês, ocorrida em 1835 na cidade do Salvador ${ }^{64}$, e da tentativa de invasão da Ilha de Itaparica, por revoltosos separatistas ligados a Francisco Sabino, em novembro de $1837^{65}$. As primeiras décadas do século XIX foram mesmo marcadas por instabilidades, resultantes de movimentos separatistas, revoltas escravas e rebeldia de libertos ocorridas em várias partes da Bahia, conforme asseverou o historiador João Reis, em seu importante estudo, ao falar da inquietude dos escravos naquela época ${ }^{66}$.

Somente por volta da década de cinqüenta é que a situação veio a se arrefecer parcialmente, ao menos na Ilha de Itaparica. A redução acelerada do número de cativos nas fazendas pode ter sido apenas um dos motivos da diminuição da densidade de fontes dando conta de conflitos, movimentos de cativos e penas de execução naquele lugar. Mas os crimes cometidos pelos escravos contra seus senhores continuaram a acontecer na cidade de Nazaré, vila de Jaguaripe e em outras paróquias pertencentes àquela Comarca ${ }^{67}$. As diversas fontes do perío-

\footnotetext{
${ }^{63}$ Ver os estudos de SCHWARTZ, Stuart B. Escravos, roceiros e rebeldes. Bauru-SP: EDUSP, 2001; MATTOSO, A Bahia no Século XIX. Op.Cit.;BARICKMAN, Op.Cit.: DIAS, Forros e brancos pobres na sociedade colonial do Brasil: 1675 - 1835. In: Op.Cit.; DIAS, Sociabilidades sem história: votantes pobres no império: 1824 - 1881. In: FREITAS, Marcos Cézar de (org.). Op.Cit.

${ }^{64}$ REIS, João José. Rebelião Escrava no Brasil: A História do Levante dos Malês em 1835. Edição revista e ampliada. São Paulo: Cia das Letras, 2003. Ver também, SILVA, Alberto da Costa e. Sobre a rebelião de 1835 na Bahia. In: Revista Brasileira. Fase VII, abril-maiojunho 2002, ano VIII, n. 31, p. 9-33.

${ }^{65}$ SOUZA, Op.Cit., p. 38. Ver também, APEB-Juízes de Itaparica, 1837-1844. Série-Judiciária. Seção Colonial/Provincial, maço 2420. Correspondência do Juiz de Paz da Vila de Itaparica ao Presidente da Província que se encontrava a bordo do navio Brigue 3 de maio, datada de 19 de novembro de 1837. Nela, o juiz avisa ao Presidente que os revoltosos atacaram e tentaram tomar de assalto Itaparica naquela data.

${ }^{66}$ REIS, Quilombos e Revoltas Escravas no Brasil. In: Op.Cit.

${ }^{67}$ Em 1853, o escravo africano, de nome Antonio, assassinou a golpes de machado o seu senhor na Vila de Jaguaripe e foi condenado a pena máxima pelo Júri de Nazaré. APEBSeção Colonial/Provincial. Juízes. Nazaré, 1853, maço 2505.
} 
do, escrutinadas com muita acuidade e valorizadas nas suas entrelinhas, informam que os escravos daquelas localidades tinham muito pouca paciência com senhores inescrupulosos e malvados. Conta uma passagem num livro de memórias, encontrado despretensiosamente no Arquivo pouco organizado de Nazaré das Farinhas, que na noite de 13 de setembro de 1866 doze negros escravos assassinaram a golpes de cacetadas o seu senhor, o coronel Joaquim Porphirio de Souza, no momento em que este firmara o pé direito no primeiro degrau da escada de seu belo e espaçoso sobrado, situado no beco em frente à ponte da Conceição, ao retornar de um enterro.

Relata ainda aquele conto, estarrecedor e macabro, que o coronel Porphirio, conhecido na cidade por Quincas, era homem extremamente cruel, tratava seus cativos com bastante rigor, não lhes concedia descanso e nem tolerava festejos. Embora tivessem plena consciência de que o terreno sobre o qual lutavam lhes era amplamente desfavorável, na maior parte das vezes, os escravos buscaram equilibrar as relações de poder e de força, adotando um poderoso mecanismo de resistência e de insubordinação, o qual era certamente muito temido pelos senhores : o elemento surpresa.

Nesse sentido, os rituais de execução dos pretos em praça pública demonstravam a sua ineficácia em intimidar os cativos e em apagar as reminiscências deixadas para a posteridade das múltiplas formas de resistência escrava, reafirmando a certeza de que as pessoas tinham o pleno conhecimento de que eles sabiam reagir no momento adequado e, de forma planejada, combinavam a morte de seus senhores virulentos. Eis uma parte da história que ficou gravada na memória dos nazarenos. O registro diz o seguinte :

Joaquim Porphirio, o Quincas, era mau e muito mau, como contam os antigos nazarenos, tratava os seus escravos com trabalhos cançantes, negava a liberdade aos pobres sofredores que os outros senhores facultavam aquelles infelizes. Era sabido que os negros procuravam às horas de silêncio em comunhão de pensamentos e lagrimas, ajuelhados, exclamavam á divindade, de braços levantados para o céo, fitando suas bellas estrellas, transmitiam pelo telegrapho do pensamento liberdade e descanso pois, basta lembrar que Quincas tinha o garbo de dizer que já tinha dado fim a 350 negros na táca. Contam também alguns antigos de Nazaré, que o Quincas não vacilava para botar negro na fornalha para coser assucar ${ }^{68}$.

${ }^{68}$ Texto extraído de um livro de memórias do Arquivo Municipal de Nazaré das Farinhas. Sem título e sem catalogação. 
Provavelmente há uma boa dose de exagero no relato que descreveu o crime cometido pelos escravos injuriados pelo seu senhor em Nazaré das Farinhas, assim como as suas gabas em dar conta de cativos. Mas certamente tal episódio deve ter provocado grande repercussão e comoção social na época, além de ter alertado a outros senhores e autoridades daquela região para o fato de que o trato da escravaria não devia passar exclusivamente pelo âmbito da violência pura e simples. Ao lado dos castigos, uma boa dose de prática paternalista e concessões à escravaria poderiam abrandar as tensões entre cativos e senhores, acreditavam veementemente nisso tanto alguns fazendeiros quanto as autoridades do lugar ${ }^{69}$.

Uma das negociações básicas dizia respeito às duras jornadas de trabalho. O relaxamento da dura disciplina do trabalho cativo foi, por assim dizer, uma questão incontestável e os senhores tiveram de admitir que, ao longo da escravatura, os cativos construíram uma cultura de resistência, a partir do acúmulo de suas experiências e quotidianamente formulavam uma pedagogia de luta, cujas estratégias podiam variar de forma e de conteúdo, dependendo das condições do momento por eles vivenciadas e estudadas ${ }^{70}$. Os crimes cometidos por eles confirmaram isso.

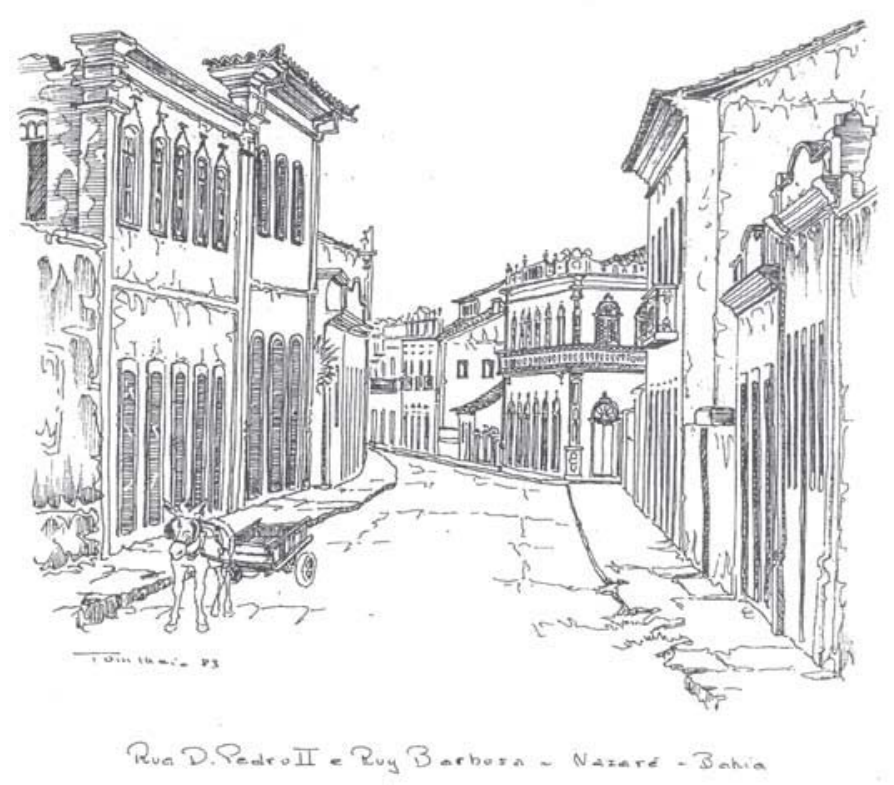

Litografia : Ruas de Nazaré das Farinhas ${ }^{71}$. 


\section{3- Africanos clandestinos e os poderes locais.}

No segundo quartel do mesmo século, um outro componente viria trazer preocupação para os poderes locais, muitas vezes cúmplices e comprometidos com certas ilegalidades do regime escravista : a circulação de africanos e as suspeitas de tráfico clandestino de escravos, os quais sempre apareciam estranhamente na cidade de Nazaré e vilas adjacentes ${ }^{72}$. Tais suspeitas foram reforçadas após o navio Relâmpago ter, em 1851, desembarcado centenas de africanos no litoral de Itaparica e os traficantes terem sido punidos primeiramente e recebido o perdão dois anos após o fato ${ }^{73}$. Contra a continuidade do tráfico alertava a Presidência da Província pedindo rigor na fiscalização do litoral daquela Comarca, que compreendia Itaparica e Jaguaripe, de modo a se evitar a circulação de negros suspeitos. Em resposta, datada de 23 de julho de 1851, o juiz de Direito de Nazaré afirmava o seu empenho no cumprimento da lei e o compromisso no combate ao fim do infame comércio de escravos :

Tendo á 20 do corrente recebido o fficio de V.Excia. com data de 14, em que vem ordenar, que tenha na maior vigilância o litoral desta Comarca, á fim de que, mediante as providencias que V.Excia especifica, sem prejuiso dar diligencias, de que trata a lei de 4 de setembro do anno passado, se possa obter a extincção do Trafico de africanos, em que o gover-

\footnotetext{
${ }^{69}$ Acerca dessa discussão acredito ser importante a leitura de MARQUESE, Rafael de Bivar. Paternalismo e governo dos escravos nas sociedades escravistas oitocentistas: Brasil, Cuba e Estados Unidos. In: FLORENTINO, Manolo e MACHADO, Cacilda (org.). Ensaios sobre a escravidão. Belo Horizonte: UFMG, 2003, p. 121 - 141. Também ver os estudos de SCHWARTZ. Segredos Internos. Op.Cit. e MATTOSO, Kátia M. de Queiroz. Ser escravo no Brasil. São Paulo: Brasiliense, 1988.

${ }^{70}$ Uma importante obra que aponta as múltiplas formas de resistência escrava e o modo como os cativos pensavam e agiam é o trabalho de BERLIN, Ira. Gerações de Cativeiro: Uma História da Escravidão nos Estados Unidos. São Paulo/Rio de Janeiro: Editora Record, 2006. ${ }^{71}$ MAIA, Op.Cit.

${ }^{72}$ Correspondência do Juiz Municipal de Nazaré ao Presidente da Província. Nazaré, 1851. APEB-Seção Colonial/Provincial. Série - Judiciário, maço 2505.

${ }^{73}$ RODRIGUES, Jaime. Op.Cit., p. 140. Ver também, HABSBURGO, Maximiliano de. Bahia 1860. Esboço de Viagem. Salvador/ Rio de Janeiro: Fundação Cultural do Estado da Bahia, 1982, p. 153. Ver também CONRAD. Op.Cit.
} 
no Imperial está empenhado, cabe-me diser em resposta, que já recomendei muito este particular aos juise municipaes dos Termos d'Itaparica, e Jaguaripe, nos quaes está comprehendido o litoral d'esta Comarca; assegurando á V. Excia, que não só procurarei fiscalisar o exacto cumprimento d'esta determinação de V.Excia, que á elles transmitti, como que pela ma parte empregarei os meios, que estiverem ao meo alcance, dando a V.Excia. prompta, e minuciosa parte do que occorrer, conforme couberem me ordena V.Excia. ${ }^{74}$.

Expressava otimismo aquele Juiz, mas talvez seu parecer não correspondesse à realidade daquela Comarca, coisa recorrente em outras localidades. Um dos maiores entraves para o cumprimento e execução da lei de $1831^{75}$ eram os conflitos de interesses que muitas vezes colocaram senhores de escravos de um lado e poder imperial de outro ${ }^{76}$. Lidar com a questão da abolição do tráfico era algo delicado e, muitas vezes, durante vinte anos, senhores corromperam e conspiraram com funcionários públicos para fazerem vistas grossas à entrada de cativos novos na Comarca de Nazaré ${ }^{77}$. O governo Imperial reagiu decretando medidas que impediriam a ascensão promocional de chefes de polícia, subdelegados, magistrados e autoridades municipais que estivessem envolvidos com o comércio ilegal de escravos, como a demissão sumária em caso de comprovação de ligação com o delito ${ }^{78}$.

No plano local, todavia, uma das formas encontradas pelas autoridades provinciais para tentar banir o tráfico, foi recomendar aos poderes municipais que estimulassem os próprios escravos a denunciar seus senhores quando ocorresse aquisição de africanos após 1850, quando a Inglaterra decidiu intensificar,

\footnotetext{
${ }^{74}$ APEB - Série Judiciária. Juízes. Nazaré, 23 de julho de 1851. Seção Colonial/Provincial, maço 2505. Ver também, correspondência enviada pelo mesmo juiz em 23 de novembro de 1851.

${ }^{75}$ Refiro-me à Legislação de 07 de novembro de 1831, a qual determinava que todo africano que ingressasse após aquela data como cativo no Brasil seria considerado livre. Ver. CONRAD. Os Últimos Anos da Escravatura no Brasil. Op.Cit., p. 32; BETHELL. Leslie. A Abolição do Comércio Brasileiro de Escravos. Brasília: Senado Federal, Conselho Editorial, 2002, Cap. IV, p. 113-48.

${ }^{76}$ Sobre isso ver, RODRIGUES. Op.Cit.; BARICKMAN. Mão de Obra. In: Op.Cit.

${ }^{77}$ APEB - Série Judiciária. Juízes. Nazaré, 21 de fevereiro de 1853. Seção Colonial/Provincial, maço 2505 .

${ }^{78}$ BETHELL Leslie. Op.Cit., p. 388.
} 
de modo ostensivo, a fiscalização em navios negreiros ${ }^{79}$. Assim é que, ao ter certeza de que alguns funcionários de outras localidades estavam envolvidos naquela questão ilegal, e após ter recebido correspondência da Presidência da Província, o Juiz de Direito de Nazaré respondeu da seguinte forma :

De posse do officio de V.Exa. de 10 do corre. q acompanhou pr copia o aviso do Ministério da Justiça de 25 de 9 bro ultimo, acerca do modo pr q se deve proceder a favor dos escravos, q depuserem em juízo contra seus senres (senhores-grifos meus), cumpri-me em resposta asserverar a V.Exa. q darei plena execução, pela parte q me toca, qdo se offerecer casos idênticos nesta Comca.

Deos Guarde a V.Exa. Nazareth 21 de fevereiro de $1853^{80}$.

Há probabilidade - e seria tentador acreditar na hipótese - de que alguns escravos teriam usado esse dispositivo a seu favor e buscado denunciar os seus senhores de modo a se beneficiar daquela recomendação da Presidência da Província no sentido de conseguirem a sua liberdade. Infelizmente, até o presente momento, a documentação disponível não autoriza fazer afirmativa a esse respeito.

Também ainda não é possível avaliar, de modo mais preciso, quantos africanos clandestinos ingressaram na Comarca de Nazaré, onde foram parar e como passaram a viver nas diversas paróquias daquela Comarca. As informações são esparsas e vagas, dificultando assim uma melhor compreensão de suas trajetórias. Sabe-se, contudo, que, por volta de 1851, havia cerca de 20 africanos livres que ficaram isentos de receber carta precatória que os intimava a pagar impostos pelo exercício de mercadejar, pelo fato de não terem como saldar tais tributos. Outros dois haviam sido computados pelo coletor de impostos, mas verificou-se que se tratava de escravos matriculados e seus senhores estavam quites com as taxas anuais ${ }^{81}$. Provavelmente todos eles haviam ingressado an-

\footnotetext{
${ }^{79}$ Dentre outras importantes obras é importante destacar, sobre esse assunto, além de BETHELL. Op.Cit. Ver também CONRAD. Os Últimos Anos da Escravatura no Brasil. Op.Cit.

${ }^{80}$ APEB - Série Judiciária. Juízes. Nazaré, 21 de fevereiro de 1853. Seção Colonial/Provincial, Maço 2505.

${ }^{81}$ APEB - Série Judiciária. Juízes. Nazaré, 10 de janeiro de 1851. Seção Colonial/Provincial, maço 2505.
} 
tes de 1851 e teriam conseguido a liberdade a partir da compra de suas alforrias, como ocorrera na maior parte das vezes.

Ao longo desse texto, verificou-se que durante a primeira metade do século XIX as autoridades locais, representantes de um estado precário, se debateram entre manter a ordem sobre a classe escrava, por meio de uma rígida repressão e execuções sumárias, e a criação de mecanismos para o enquadramento dos libertos, cuja liberdade de se moverem criava imensas dificuldades em mantê-los sob vigilância e rigorosa disciplina do trabalho, principal expediente de manutenção da ordem. Nesse sentido, o recurso dos recrutamentos para os forros e a condenação em praça pública para os escravos se constituíram em poderosas armas para a manutenção da ordem pública num momento decisivo para as pretensões das elites, formuladoras do estado nacional.

Por sua vez, tanto escravos quanto os forros demonstraram, por meio de variadas formas de lutas individuais e coletivas, que nunca estiveram dispostos a se submeter docilmente aos projetos da sociedade na qual estavam inseridos. Para os primeiros, a liberdade nunca se constituiu em uma miragem inatingível, por isso eles reagiram violentamente nas diversas ocasiões contra seus senhores. Para os segundos, a liberdade significou mais do que uma carta de liberdade e o fato de não mais se submeterem a um senhor; ela era, antes de qualquer coisa, a possibilidade de se mover e de determinar as condições e os modos pelos quais eles desejavam sobreviver, inclusive o de determinar o direito de não trabalhar ${ }^{82}$.

\footnotetext{
${ }^{82}$ Sobre a experiência de liberdade e a mobilidade dos libertos, ver MATTOS, Hebe Maria. Das Cores do Silêncio. Os significados da Liberdade no Sudeste Escravista. Brasil Séc. XIX. $3^{\text {a }}$ reimpressão, Rio de Janeiro: Nova Fronteira, 1998. Sobretudo, o capítulo 1: Uma Experiência de Liberdade. Ver também, FONER, Eric. Nada Além da Liberdade: a emancipação e o seu legado. Rio de Janeiro: Paz e Terra, Brasília, CNPQ, 1988.
} 


\section{Referências Bibliográficas}

BARICKMAN, B. J. Um Contraponto Baiano : açúcar, fumo, mandioca e escravidão, 1780 - 1860. Rio de Janeiro : Civilização Brasileira, 2003.

BERLIN, Ira. Gerações de Cativeiro. Uma História da Escravidão nos Estados Unidos. São Paulo/Rio de Janeiro : Editora Record, 2006.

BETHELl Leslie. A Abolição do Comércio Brasileiro de Escravos. Brasília : Senado Federal, Conselho Editorial, 2002.

BITHENCOURT, Francisco. História das Inquisições : Portugal, Espanha e Itália. Séculos XV-XIX. São Paulo : Cia das Letras, 2000.

CONRAD, Robert. Os Últimos Anos de Escravatura no Brasil : 1850 - 1888. Rio de Janeiro : Civilização Brasileira, 1978.

Tumbeiros : O tráfico de Escravos para o Brasil. São Paulo : Brasiliense, 1985.

DELUMEAU, Jean. História do Medo no Ocidente. 1300-1800. São Paulo : Cia. das Letras, 1999.

DIAS, Maria Odila Leite da Silva. Forros e Brancos Pobres na Sociedade Colonial do Brasil, 1675-1835. In : História General da América Latina. Unesco, Madri, Trota, Vol. 3, 2001.

Sociabilidades sem História : Votantes Pobres no Império, 1824-1881. In : FREITAS, Marcos Cézar de (org.). Historiografia Brasileira em Perspectiva. São Paulo : Contexto, 1998.

ELLIS, Miriam. A Baleia no Brasil Colonial. São Paulo : Edusp, 1968.

FONER, Eric. Nada Além da Liberdade : a emancipação e o seu legado. Rio de Janeiro : Paz e Terra; Brasília : CNPQ, 1988.

FRAGA FILHO, Walter. Mendigos, Moleques e Vadios na Bahia do Século XIX. São Paulo : HUCITEC; Salvador, EDUFBA, 1996.

Encruzilhadas da Liberdade : Histórias e Trajetórias de Escravos e Libertos na Bahia : 1870-1910. Tese de Doutorado. Instituto de Filosofia e Ciências Humanas da Universidade de Campinas, Unicamp, 2004.

HABSBURGO, Maximiliano de. Bahia 1860. Esboço de Viagem. Salvador/ Rio de Janeiro : Fundação Cultural do Estado da Bahia, 1982. 
KRAAY, Hendrik. Em outra coisa não falavam os pardos, cabras, e crioulos : O 'recrutamento' de escravos na Guerra da Independência na Bahia. In : Revista Brasileira de História. São Paulo : Vol. 22, n. 43, 2002.

MACHADO, Cacilda (org.). Ensaios sobre a escravidão. Belo Horizonte : UFMG, 2003.

MAIA, Tereza Regina de Camargo. Velha Bahia de Hoje. Rio de Janeiro : Exped, 1985.

MARQUESE, Rafael de Bivar. Paternalismo e governo dos escravos nas sociedades escravistas oitocentistas : Brasil, Cuba e Estados Unidos. In : FLORENTINO, Manolo e MACHADO, Cacilda (org.). Ensaios sobre a escravidão. Belo Horizonte : UFMG, 2003.

MATTOS, Hebe Maria. Das Cores do Silêncio. Os significados da Liberdade no Sudeste Escravista. Brasil Séc. XIX. $3^{\text {a }}$ reimpressão, Rio de Janeiro : Nova Fronteira, 1998.

MATTOSO, Kátia M. de Queiroz. Bahia : A cidade do Salvador e seu mercado no século XIX. São Paulo : Hucitec; Salvador : Secretaria Municipal de Educação e Cultura, 1978.

A Bahia no Século XIX : uma Província no Império. Rio de Janeiro : Nova Fronteira, 1992.

Ser escravo no Brasil. São Paulo : Brasiliense, 1988.

OSÓRIO, Ubaldo. A Ilha de Itaparica : História e Tradição. Salvador : Fundação Cultural do Estado da Bahia, 1979.

REIS, João José. Quilombos e Revoltas Escravas no Brasil. In : Revista USP. São Paulo : EDUSP, n. 22, 1989.

A Morte é Uma Festa. São Paulo : Cia das Letras, 1991.

Rebelião Escrava no Brasil. A História do Levante dos Malês em 1835. Edição revista e ampliada. São Paulo : Cia das Letras, 2003.

RODRIGUES, Jaime. O Infame Comércio : Propostas e Experiências no Final do Tráfico de Africanos para o Brasil (1800-1850). São Paulo : Editora da Unicamp, 2000.

SCHWARTZ. Stuart B. Segredos Internos. Engenhos e Escravos na Sociedade Colonial. São Paulo : Cia das Letras, 1995.

Escravos, roceiros e rebeldes. Bauru-SP : EDUSP, 2001.

SILVA, Alberto da Costa e. Sobre a rebelião de 1835 na Bahia. In : Revista Brasileira. Fase VII, ano VIII, n. 31, abril-maio-junho de 2002. 
SOUZA, Paulo Cézar. A Sabinada. A revolta Separatista da Bahia. (1837). São Paulo : Brasiliense, 1987.

SPIX e MARTIUS. Viagem pelo Brasil. 1818-1820. Vol. 2, São Paulo : Edusp, 1981.

VILHENA, Luís dos Santos. A Bahia No Século XVIII. Vol. 03. Salvador : Editora Itapuã, 1969.

XIMENES, Cristiana Ferreira Lírio. Joaquim Pereira Marinho : Perfil de um Contrabandista de Escravos na Bahia, 1828-1887. Dissertação de Mestrado, Universidade Federal da Bahia, Faculdade de Filosofia e Ciências Humanas, Mestrado em História. Salvador : UFBA, 1999. 